\title{
Variation in Productive Efficiency in French Workers' Cooperatives*
}

\author{
JACQUES DEFOURNY \\ University of Liège and CIRIEC \\ C.A. KNOX LOVELL \\ University of North Carolina \\ AKÉ G.M. N'GBO \\ University of Abidjan and CIRIEC
}

\section{Abstract}

In this study, we explore the distribution of productive efficiency among workers' cooperatives operating in each of four sectors of French manufacturing. We use stochastic trontier panel data techniques to estimate production relationships in each sector, and to decompose output variation into input variation, variation in the effects of two indicators of the degree of worker participation in management, variation in productive efficiency, and an unexplained residual. In all four scetors we find that conventionally measured capital and labor inputs make a significant contribution to productivity. In only one sector do participation indicators contribute significantly. Variation in productive efficiency contributes significantly in all four sectors.

\section{Introduction}

The purpose of this study is to explore the distribution of productive efficiency among workers' cooperatives operating in each of four sectors of French manufacturing. Productive efficiency is one component of overall productivity, and although the measurcment of productivity change (or variation) in European cooperatives has attracted much attention recently, for a variety of reasons the technical efficiency component of productivity change has been almost completely neglected. This study is an effort to remedy that neglect.

We have recent data on output, inputs, and other relevant variables for a number of workers' cooperatives operating in each of four sectors of French manufacturing for the two adjacent years 1987 and 1988. The sectors are architecture, printing, furniture, and public works. Thus we have four short two-year panels containing 24, 55, 22 and 42 firms, respectively.

We use recently developed stochastic frontier panel data techniques to estimate the production relationships within each sector. These techniques provide a decomposition of output variation into input variation, variation in a pair of variables representing the degree of participation of workers in management, variation in technical efficiency, and an unexplained residual. ${ }^{1}$

*Earlier versions of this article were presented at the ORSA/TIMS Joint National Meeting in Philadelphia, PA, October 1990, and at the Allied Social Science Associations meetings in Washington, DC, December 1990. Helpful comments from discusants at both meetings, and from two good referees, are gratefuly acknowledged, as is financial support of AUPELF and the UNC University Research Council. 
The decomposition of productivity variation into input variation and participation variation is not new in this literature; see Jones and Svejnar [1985], Defourny, Estrin and Jones [1987], Defourny [1987] and Estrin, Jones and Svejnar [1987] for applications of this technique. The introduction of an additional component-efficiency variation-is new. Only Defourny [1988] and Sterner [1990] have sought to measure the technical efficiency of workers' cooperatives, in several sectors of the French economy and in the Mexican cement industry, respcctively. However, Defourny cstimatcd the mean technical efficiency, rather than individual efficiencies, over all cooperatives and over all capitalist firms in each sector. Consequently, he did not use efficiency variation to expiain any part of intra-sectoral productivity variation. ${ }^{2}$ Sterner compared technical efficiencies of individual plants with different ownership structures, but there were only two cooperatives in his sample. ${ }^{3}$

In all four sectors we find that conventionally measured capital and labor inputs make a significant contribution to productivity. In only two sectors do participation indicators contribute significantly. Variation in technical efficiency contributes significantly in all four sectors. One conclusion to be drawn from these findings is that it is risky to analyze productivity variation under the assumption of technical efficiency. To do so leads to an erroneous allocation of productivity variation to its other sources, which in turn can lead to inappropriate policy decisions, particularly those that may be designed to influence participation.

This article is organized as follows: in Section 2 we outline the production frontier model, its characteristics and its estimation; Section 3 contains a brief description of the data, and a discussion of the empirical results; and Section 4 concludes with a summary of the study and suggestions for further related research.

\section{The Production Frontier Model}

For a single cross section, Aigner, Lovell, and Schmidt [1977], Battese and Corra [1977] and Meeusen and van den Broeck [1977] all showed how to estimate a stochastic production frontier model of the form

$$
\ln y_{i}=\alpha_{0}+\sum_{j=1}^{K} \alpha_{j} \ln x_{j i}+v_{i}+u_{i}, \quad i=1, \ldots, I,
$$

where $\mathrm{y}_{\mathrm{i}}$ is observed output in the $i$ th firm, $\mathrm{x}_{\mathrm{ji}}$ is the observed amount of the $j$ th input employed in the $i$ th firm, $\left(\alpha_{0}, \alpha_{1}, \ldots, \alpha_{\mathrm{K}}\right)$ is a vector of technology parameters to be estimated, $\mathrm{v}_{\mathrm{i}} \sim \mathrm{N}\left(0, \sigma_{\mathrm{v}}^{2}\right)$ is an error term capturing the random effects of noise, measurement error and the like, and $u_{i}$ is a nonpositive error term, distributed independently of $v_{i}$, capturing the effects of technical inefficiency in production. Once a particular distribution is assigned to $u_{i}-$ half normal, truncated normal, exponential and gamma have becn used-its parameter(s) can be estimated and mean technical efficiency in the sample can be estimated. This is what Defourny [1988] did, using least squares methods.

Now we consider a time series of cross sections, and write the panel data extension of the cross section production frontier model (2.1) as 


$$
\ln \mathrm{y}_{\mathrm{it}}=\alpha_{0}+\sum_{\mathrm{j}=1}^{\mathrm{K}} \alpha_{\mathrm{j}} \ln \mathrm{x}_{\mathrm{jit}}+\mathrm{v}_{\mathrm{it}}+\mathrm{u}_{\mathrm{i}}, \quad \mathrm{i}=1, \ldots, \mathrm{I}, \mathrm{t}=1, \ldots, \mathrm{T}_{\mathrm{i}},
$$

where $\mathrm{y}_{\mathrm{it}}$ is observed output of the $i$ th firm in the $t$ th period, and $\mathrm{x}_{\mathrm{jit}}$ is observed usage of the $j$ th input in the $i$ th firm in the $t$ th period. We have $I$ firms and $T=\max \left\{\mathrm{T}_{\mathrm{i}}\right\}$ periods, although not all firms must be observed in all periods. Note that technical inefficiency is captured by the "firm effect," and is time-invariant. Models of this nature have been considered by several authors recently; this particular unbalanced panel version is adapted from Battese, Coelli, and Colby [1989].

In this study we use a standard Cobb-Douglas production function ${ }^{4}$

$$
\mathrm{y}_{\mathrm{it}}=\mathrm{AK}_{\mathrm{it}}^{\alpha} \mathrm{L}_{\mathrm{it}}^{\beta} \text {, }
$$

and incorporate the following institutional features of the cooperatives

$$
\mathrm{K}_{\mathrm{it}}=\mathrm{K}_{\mathrm{it}}^{\mathrm{I}}+\mathrm{K}_{\mathrm{it}}^{\mathrm{E}}
$$

and

$$
\mathrm{L}_{\mathrm{it}}=\mathrm{L}_{\mathrm{it}}^{\mathrm{N}}+\mathrm{L}_{\mathrm{it}}^{\mathrm{M}} \text {, }
$$

where $\mathrm{K}_{\mathrm{it}}^{\mathrm{l}}$ and $\mathrm{K}_{\mathrm{it}}^{\mathrm{E}}$ denote the amounts of fixed assets financed internally and externally, respectively, and where $L_{i t}^{N}$ and $L_{i t}^{M}$ denote the number of employees who are non-members and members of the cooperative, respectively, all in firm $\mathrm{i}$ in period t. ${ }^{5}$ We now rewrite equation (3) as

$$
\mathrm{y}_{\mathrm{it}}=\mathrm{AK}_{\mathrm{it}}^{\alpha}\left[( 1 + ( \mathrm { d } - 1 ) ( \mathrm { K } _ { \mathrm { it } } ^ { \mathrm { E } } / \mathrm { K } _ { \mathrm { it } } ) ] ^ { \alpha } \mathrm { L } _ { \mathrm { it } } ^ { \beta } \left[\left(1+(\mathrm{c}-1)\left(\mathrm{L}_{\mathrm{it}}^{\mathrm{N}} / \mathrm{L}_{\mathrm{it}}\right)\right]^{\beta},\right.\right.
$$

where $d$ and $c$ are parameters that allow for productivity differentials between $K_{i t}^{E}$ and $K_{i t}^{I}$, and between $L_{i t}^{N}$ and $L_{i t}^{M}$, respectively. In the event that $d=c=1$, equation (6) collapses to equation (3), while if $\mathrm{d} \neq 1$ or $\mathrm{c} \neq 1$ there is a productivity differential between externally and internally financed fixed assets, or between nonmember and member employees. Following Brown and Medoff [1978], we take the logarithm of equation (6) and take linear approximations to the two bracketed terms to generate ${ }^{6}$

$$
\ln \mathrm{y}_{\mathrm{it}}=\ln \mathrm{A}+\alpha \ln \mathrm{K}_{\mathrm{it}}+\beta \ln \mathrm{L}_{\mathrm{it}}+\alpha(\mathrm{d}-1)\left(\mathrm{K}_{\mathrm{it}}^{\mathrm{E}} / \mathrm{K}_{\mathrm{it}}\right)+\beta(\mathrm{c}-1)\left(\mathrm{L}_{\mathrm{it}}^{\mathrm{N}} / \mathrm{L}_{\mathrm{it}}\right) .
$$

After reparameterization our stochastic production frontier model becomes

$$
\ln \mathrm{y}_{\mathrm{it}}=\mathrm{a}_{0}+\mathrm{a}_{1} \ln \mathrm{K}_{\mathrm{it}}+\mathrm{a}_{2} \ln \mathrm{L}_{\mathrm{it}}+\mathrm{a}_{3}\left(\mathrm{~K}_{\mathrm{it}}^{\mathrm{E}} / \mathrm{K}_{\mathrm{it}}\right)+\mathrm{a}_{4}\left(\mathrm{~L}_{\mathrm{it}}^{\mathrm{N}} / \mathrm{L}_{\mathrm{it}}\right)+\mathrm{v}_{\mathrm{it}}+\mathrm{u}_{\mathrm{i}} .
$$

The disturbance component $v_{i t}$ is assumed to be independently and identically distributed as $\mathrm{N}\left(0, \sigma_{\mathrm{v}}^{2}\right)$, independent of the disturbance component $\mathrm{u}_{\mathrm{i}}$, which is assumed to be independently and identically distributed as the nonpositive part of a $\mathrm{N}\left(\mu, \sigma^{2}\right)$ distribution 
truncated above at zero. Both components are also assumed to be distributed independently of the exogenous variables in the model.

Firm-specific but time-invariant estimates of technical efficiency are obtained by following Jondrow et al. [1982] and Battese and Coelli [1988] to obtain

$$
\mathrm{TE}_{\mathrm{i}}=\mathrm{E}\left[\exp \left(\mathrm{u}_{\mathrm{i}} \mid \mathrm{v}_{\mathrm{it}}+\mathrm{u}_{\mathrm{i}}\right)\right]=\left\{\frac{1-\mathrm{F}\left(\sigma_{\mathrm{i}}^{*}+\left(\mu_{\mathrm{i}}^{*} / \sigma_{\mathrm{i}}^{*}\right)\right]}{1-\mathbf{F}\left(\mu_{\mathrm{i}}^{*} / \sigma_{\mathrm{i}}^{*}\right)}\right\} \exp \left(\mu_{\mathrm{i}}^{*}+1 / 2 \sigma_{\mathrm{i}}^{* 2}\right),
$$

where $\mathrm{F}\left({ }^{-}\right)$is the cumulative distribution function of the standard normal variable and $\mu_{i}^{*}$ and $\sigma_{i}^{* 2}$ are the parameters of the conditional normal distribution of $\left.\left(u_{i}\right) v_{i t}+u_{i}\right)$. The mean technical efficiency of all firms in a sector is given by

$$
\mathrm{TE}=\left\{\frac{1-\mathrm{F}[\sigma+(\mu / \sigma)]}{1-\mathrm{F}(\mu / \sigma)}\right\} \exp \left(\mu+1 / 2 \sigma^{2}\right) .
$$

Equation (8) is the model to be estimated, after which equations (9) and (10) are used to estimate time-invariant efficiency by observation and as a sample mean.

There are eight parameters to be estimated. The three technology parameters $\left(a_{0}, a_{1}\right.$, $a_{2}$ ) describe the contribution of conventionally measured capital and labor inputs to output. The two participation parameters ( $d$ and $c$ ) measure the contribution of two popular indicators of participation to output. The three efficiency parameters $\left[\mu, \tilde{\sigma}^{2}=\sigma^{2}+\sigma_{\mathrm{v}}^{2}\right.$ and $\left.\gamma=\sigma^{2} / \tilde{\sigma}^{2}\right]$ describe the contribution of technical efficiency to output. All eight parameters are estimated using maximum likelihood techniques described in Battese, Coelli, and Colby [1989] and Coelli [1989].

\section{The data and the results}

We use panel data covering 1987 and 1988 for cooperatives in four sectors: in Architecture we have 24 firms and 45 observations, in Printing, we have 55 firms and 110 observations, in Furniture we have 22 firms and 41 observations, and in Public Works we have 42 firms and 81 observations. Output $y_{i t}$ is value added in thousand FF, capital $K_{i t}$ is the value of fixed assets in thousand FF, labor $\mathrm{L}_{\mathrm{it}}$ is the number of employees, and $\mathrm{K}_{\mathrm{it}}^{\mathrm{E}} / \mathrm{K}_{\mathrm{it}}$ and $\mathrm{L}_{\mathrm{it}}^{\mathrm{N}} / \mathrm{L}_{\mathrm{il}}$ are ratios of external capital to total capital and non-member workers to total workers, respectively. The data were obtained from CGSCOP [1989], and are summarized in table 1.

Having only two years of data, we think the fixed effects model gives reliable estimates of technical efficiency. We use maximum likelihood methods to obtain estimates of $a_{0}, a_{1}$, $\mathrm{a}_{2}, \mathrm{a}_{3}, \mathrm{a}_{4}, \mu, \tilde{\sigma}^{2}$ and $\gamma$ and their standard errors. ${ }^{8}$ The participation parameters $\mathrm{c}$ and $\mathrm{d}$ are also identified, and so we estimate them and their standard errors as well. ${ }^{9}$ The results for each of the four sectors are presented in tables 2-5. Each table reports the results of four model specifications, in which different restrictions are imposed on the parameters. Student $t$-statistics are reported beneath parameter estimates. The $\chi^{2}$ statistic provides a test of the hypothesis that variation in technical efficiency contributes nothing to productivity variation; the hypothesis is that $\gamma=0$. 
Table 1. Data.

\begin{tabular}{|c|c|c|c|c|c|}
\hline & $\begin{array}{c}\mathrm{y} \\
\text { (Thousand FF) }\end{array}$ & $\begin{array}{c}\text { K } \\
\text { (Thousand FF) }\end{array}$ & $\begin{array}{c}\text { L } \\
\text { (Number of Employees) }\end{array}$ & $\mathbf{K}^{\mathrm{E}} / \mathbf{K}$ & $\mathrm{L}^{\mathrm{N}} / \mathrm{L}$ \\
\hline \multicolumn{6}{|c|}{ Furniture } \\
\hline Mean & 4373.92 & 3128.02 & 28 & 0.13 & 0.26 \\
\hline Min & 96.12 & 144.18 & 3 & 0.0 & 0.0 \\
\hline $\operatorname{Max}$ & 93133.51 & 83150.54 & 409 & 0.46 & 0.70 \\
\hline \multicolumn{6}{|l|}{ Printing } \\
\hline Mean & 3659.63 & 2941.38 & 20 & 0.12 & 0.23 \\
\hline Min & 61.00 & 80.64 & 2 & 0.0 & 0.0 \\
\hline $\operatorname{Max}$ & 20206.99 & 21105.36 & 88 & 0.75 & 0.69 \\
\hline \multicolumn{6}{|c|}{ Public Works } \\
\hline Mean & 8276.71 & 4189.22 & 44 & 0.16 & 0.43 \\
\hline Min & 390.94 & 26.80 & 2 & 0.0 & 0.0 \\
\hline $\operatorname{Max}$ & 66123.66 & 44846.77 & 343 & 0.99 & 0.90 \\
\hline \multicolumn{6}{|c|}{ Architecture } \\
\hline Mean & 1100.46 & 227.51 & 5 & 0.10 & 0.15 \\
\hline Min & 253.23 & 8.96 & 2 & 0.0 & 0.0 \\
\hline $\operatorname{Max}$ & 3217.74 & 1037.63 & 18 & 0.43 & 0.55 \\
\hline
\end{tabular}

As mentioned in the introduction, we seek to quantify the contributions of three sources of productivity variation. Although there are clear differences across the four sectors, we provide a functional summary of the results by focusing on the contributions of inputs, participation and efficiency to output in the four sectors.

The role of inputs: Estimated output-capital elasticities are stable across models, with values in the $(0.1,0.2)$ range, and are frequently significantly greater than zero. Estimated output-labor elasticities are also stable across models, with values in the (0.9-1.0) range, and are always significantly greater than zero. Consequently, scale economies appear to play a role in all four sectors, with estimated scale elasticities falling in the (1.0-1.2) range, although they are only occasionally significantly greater than unity.

The role of participation: One way of measuring the impact of participation is to examine the estimated coefficients on the two participation variables. These estimated coefficients are not significantly different from zero in two sectors (Architecture and Public Works); they are suggestively close to being significantly different from zero in the Furniture sector; and they are clearly significantly different from zero in the Printing sector. Where significant, these cstimated coefficients are negative, suggesting that incrcased participation leads to increases in output. A second way of measuring the impact of participation on output is through use of likelihood ratio tests, which we leave to the reader. These tests tell much the same story. A third way of measuring the impact of participation is to derive estimates of $(d-1)$ and $(c-1)$ from the coefficient estimates, and then to calculate approximate standard errors of the estimated values of $(d-1)$ and $(c-1)$, respectively. Results of these calculations are consistent with the first two sets of tests, and suggest that participation indicators exert a significantly positive impact on output in the Printing sector, and they come close to doing so in the Furniture sector. They do not have a significant 
Table 2. Panel frontier results for architecture cooperatives. Dependent Variable: $\ln y_{\text {it }}$

\begin{tabular}{|c|c|c|c|c|c|}
\hline \multirow{3}{*}{$\begin{array}{l}\text { Independent } \\
\text { Variable }\end{array}$} & \multirow[b]{3}{*}{ Coefficient } & \multicolumn{4}{|c|}{ MLE Parameter Estimates } \\
\hline & & \multicolumn{4}{|c|}{ Model } \\
\hline & & 1 & 2 & 3 & 4 \\
\hline Constant & $a_{0}$ & $\begin{array}{c}4.2310 \\
(12.5588)\end{array}$ & $\begin{array}{c}4.1966 \\
(12.6411)\end{array}$ & $\begin{array}{c}4.2294 \\
(12.6588)\end{array}$ & $\begin{array}{r}4.1955 \\
(12.5725)\end{array}$ \\
\hline $\ln K_{i t}$ & $a_{1}$ & $\begin{array}{c}0.2144 \\
(4.1791)\end{array}$ & $\begin{array}{c}0.2060 \\
(4.3046)\end{array}$ & $\begin{array}{c}0.2143 \\
(4.1762)\end{array}$ & $\begin{array}{c}0.2060 \\
(4.3086)\end{array}$ \\
\hline $\ln \mathrm{L}_{\mathrm{it}}$ & $a_{2}$ & $\begin{array}{c}1.0215 \\
(5.7717)\end{array}$ & $\begin{array}{c}1.0544 \\
(6.5458)\end{array}$ & $\begin{array}{c}1.0242 \\
(6.2137)\end{array}$ & $\begin{array}{c}1.0566 \\
(7.0454)\end{array}$ \\
\hline$\left(\mathbf{K}^{\mathrm{E} / \mathrm{K}}\right)_{\mathrm{it}}$ & $a_{3}$ & $\begin{array}{c}-0.1881 \\
(-0.4508)\end{array}$ & - & $\begin{array}{c}-0.1879 \\
(-0.4502)\end{array}$ & - \\
\hline \multirow[t]{9}{*}{$\left(\mathrm{L}^{\mathrm{N}} / \mathrm{L}\right)_{\mathrm{it}}$} & $a_{4}$ & $\begin{array}{c}0.0128 \\
(0.0431)\end{array}$ & $\begin{array}{c}0.0108 \\
(0.0363)\end{array}$ & - & - \\
\hline & $\tilde{\sigma}^{2}$ & $\begin{array}{c}0.1212 \\
(2.4415)\end{array}$ & $\begin{array}{c}0.1210 \\
(2.4440)\end{array}$ & $\begin{array}{c}0.1214 \\
(2.4577)\end{array}$ & $\begin{array}{c}0.1212 \\
(2.4755)\end{array}$ \\
\hline & $\gamma$ & $\begin{array}{c}0.2288 \\
(0.5281)\end{array}$ & $\begin{array}{c}0.2210 \\
(0.5022)\end{array}$ & $\begin{array}{c}0.2306 \\
(0.5379)\end{array}$ & $\begin{array}{c}0.2230 \\
(0.5134)\end{array}$ \\
\hline & $\mu$ & 0 & 0 & 0 & 0 \\
\hline & $\ln £$ & -12.7418 & -12.8439 & -12.7427 & -12.8445 \\
\hline & $x_{(1)}^{2}$ & 5.5029 & 4.3492 & 4.3960 & 3.2799 \\
\hline & RTS & $\begin{array}{c}1.2359 \\
(1.4908)\end{array}$ & $\begin{array}{c}1.2604 \\
(1.7528)\end{array}$ & $\begin{array}{c}1.2385 \\
(1.6411)\end{array}$ & $\begin{array}{c}1.2626 \\
(1.9150)\end{array}$ \\
\hline & $d-1$ & $\begin{array}{c}-0.8773 \\
(-0.6235)\end{array}$ & - & $\begin{array}{c}-0.8768 \\
(-0.4495)\end{array}$ & - \\
\hline & $c-1$ & $\begin{array}{c}0.0125 \\
(0.0313)\end{array}$ & $\begin{array}{c}0.0102 \\
(0.0361)\end{array}$ & - & - \\
\hline \multicolumn{6}{|c|}{ Mean Efficiencies by Cooperative } \\
\hline Firm & NOBS & & & & \\
\hline 1 & 2 & 0.8930 & 0.8898 & 0.8926 & 0.8893 \\
\hline 2 & 2 & 0.8910 & 0.8933 & 0.8904 & 0.8927 \\
\hline 3 & 2 & 0.9105 & 0.9107 & 0.9101 & 0.9103 \\
\hline 4 & 2 & 0.8902 & 0.8923 & 0.8900 & 0.8920 \\
\hline 5 & 2 & 0.9017 & 0.9050 & 0.9013 & 0.9047 \\
\hline 6 & 2 & 0.9283 & 0.9273 & 0.9280 & 0.9269 \\
\hline 7 & 2 & 0.7928 & 0.7875 & 0.7913 & 0.7859 \\
\hline 8 & 2 & 0.8818 & 0.8875 & 0.8816 & 0.8871 \\
\hline 9 & 2 & 0.9032 & 0.8981 & 0.9032 & 0.8980 \\
\hline 10 & 2 & 0.9048 & 0.9065 & 0.9044 & 0.9060 \\
\hline 11 & 1 & 0.9008 & 0.9031 & 0.9003 & 0.9026 \\
\hline 12 & 2 & 0.8884 & 0.8931 & 0.8880 & 0.8926 \\
\hline 13 & 2 & 0.8825 & 0.8821 & 0.8822 & 0.8818 \\
\hline
\end{tabular}


Table 2. continued

\begin{tabular}{cccccc}
\hline \multirow{2}{*}{ Mean Efficiencies by Cooperative } & \multicolumn{4}{c}{ MLE Parameter Estimates } \\
\cline { 3 - 6 } & & \multicolumn{4}{c}{ Model } \\
\cline { 3 - 6 } Firm & NOBS & 1 & 2 & 3 & 4 \\
\hline 14 & 2 & 0.8674 & 0.8731 & 0.8675 & 0.8731 \\
15 & 1 & 0.8775 & 0.8808 & 0.8767 & 0.8800 \\
16 & 2 & 0.8653 & 0.8682 & 0.8644 & 0.8673 \\
17 & 2 & 0.8421 & 0.8498 & 0.8417 & 0.8493 \\
18 & 2 & 0.8607 & 0.8664 & 0.8603 & 0.8659 \\
19 & 2 & 0.8842 & 0.8848 & 0.8836 & 0.8841 \\
20 & 2 & 0.8011 & 0.8062 & 0.7995 & 0.8045 \\
21 & 2 & 0.8537 & 0.8612 & 0.8527 & 0.8602 \\
22 & 2 & 0.8326 & 0.8380 & 0.8322 & 0.8375 \\
23 & 2 & 0.9233 & 0.9230 & 0.9233 & 0.9229 \\
24 & 1 & 0.9353 & 0.9357 & 0.9353 & 0.9357 \\
Overall Mean Score & & 0.8798 & 0.8818 & 0.8793 & 0.8813 \\
\hline
\end{tabular}

effect in the two remaining sectors. Our finding of a significant positive effect of participation in the Printing sector is consistent with results of Defourny, Estrin, and Jones [1987]. Among the six sectors in which they studied the performance of cooperatives, Printing also emerged as a sector in which the productivity enhancing effect of workers' participation was particularly important. This common finding may be linked to the fact that the cooperative movement has long been very active in Printing, with its skilled workers, strong personal involvement, and militancy.

The role of efficiency: Efliciency plays a substantial, and statistically significant, role in all four sectors. Estimated values of $\gamma$, the ratio of the variance of the efficiency element in the composed error term to the variance of the composed error term itself, are statistically significant in the majority of models. More to the point, the chi-square statistics, which test the improvement in explanatory power of MLE over OLS, suggest that the parameters of the one-sided component of the composed error structure are statistically significant in all cases. In all sectors the impact of inefficiency is captured by two parameters, $\sigma^{2}$ and $\gamma$; in no sector did the model converge with a statistically significant value of $\mu$.

The time-invariant estimates of technical efficiency for each cooperative enterprisc in each sector are reported in the lower half of tables 2-5. These efficiencies show little variation across models, suggesting that the specification is robust to variation in the participation component of the model. The efficiencies vary substantially across sectors, with sample means declining from 0.88 in Architecture to 0.80 in Printing, 0.77 in Public Works, and 0.74 in Furniture. The efficiencies also vary substantially within each sector, with scores in Model 1 ranging from 0.79 to 0.93 in Architecture, from 0.59 to 0.93 in Printing, from 0.45 to 0.94 in Furniture, and from 0.45 to 0.96 in Public Works. This variation in productive efficiency goes a long way toward explaining observed variation in output within each sector. 
Table 3. Panel frontier results for printing cooperatives. Dependent Variable: $\ln y_{\text {it }}$

\begin{tabular}{|c|c|c|c|c|c|}
\hline \multirow{3}{*}{$\begin{array}{c}\text { Independent } \\
\text { Variable }\end{array}$} & \multirow[b]{3}{*}{ Coefficient } & \multicolumn{4}{|c|}{ MLE Parameter Estimates } \\
\hline & & \multicolumn{4}{|c|}{ Model } \\
\hline & & 1 & 2 & 3 & 4 \\
\hline Constant & $\mathrm{a}_{0}$ & $\begin{array}{c}4.8581 \\
(21.7339)\end{array}$ & $\begin{array}{c}4.8552 \\
(21.8062)\end{array}$ & $\begin{array}{c}4.6858 \\
(21.0673)\end{array}$ & $\begin{array}{c}4.5776 \\
(19.9383)\end{array}$ \\
\hline $\ln \mathbf{K}_{\mathrm{it}}$ & $a_{1}$ & $\begin{array}{c}0.0802 \\
(2.2724)\end{array}$ & $\begin{array}{c}0.0693 \\
(1.9017)\end{array}$ & $\begin{array}{c}0.1196 \\
(3.5449)\end{array}$ & $\begin{array}{c}0.1331 \\
(3.8013)\end{array}$ \\
\hline $\ln \mathbf{L}_{\mathrm{it}}$ & $a_{2}$ & $\begin{array}{c}1.0253 \\
(15.3438)\end{array}$ & $\begin{array}{c}1.0446 \\
(15.1135)\end{array}$ & $\begin{array}{c}0.9504 \\
(16.8060)\end{array}$ & $\begin{array}{c}0.9373 \\
(15.7294)\end{array}$ \\
\hline$\left(\mathrm{K}^{\mathrm{E} / \mathrm{K}}\right)_{\text {it }}$ & $a_{3}$ & $\begin{array}{c}-0.4920 \\
(-1.8197)\end{array}$ & - & $\begin{array}{c}-0.6823 \\
(-2.6805)\end{array}$ & - \\
\hline \multirow[t]{9}{*}{$\left(\mathrm{L}^{\mathrm{N}} / \mathrm{L}\right)_{\mathrm{it}}$} & $a_{4}$ & $\begin{array}{c}-0.5284 \\
(-2.6885)\end{array}$ & $\begin{array}{c}-0.6613 \\
(-3.4813)\end{array}$ & - & - \\
\hline & $\tilde{\sigma}^{2}$ & $\begin{array}{c}0.2151 \\
(3.5142)\end{array}$ & $\begin{array}{c}0.2188 \\
(3.5430)\end{array}$ & $\begin{array}{c}0.2319 \\
(3.8753)\end{array}$ & $\begin{array}{c}0.2686 \\
(3.6509)\end{array}$ \\
\hline & $\gamma$ & $\begin{array}{c}0.4016 \\
(2.0924)\end{array}$ & $\begin{array}{c}0.3800 \\
(1.8650)\end{array}$ & $\begin{array}{c}0.4329 \\
(2.5470)\end{array}$ & $\begin{array}{c}0.5021 \\
(3.0339)\end{array}$ \\
\hline & $\mu$ & 0 & 0 & 0 & 0 \\
\hline & $\ln \mathfrak{f}$ & -53.7778 & -55.9284 & -56.2136 & -59.9991 \\
\hline & $x_{(1)}^{2}$ & 7.4121 & 6.6459 & 7.1295 & 7.9143 \\
\hline & RTS & $\begin{array}{c}1.1055 \\
(1.8178)\end{array}$ & $\begin{array}{c}1.1139 \\
(1.9213)\end{array}$ & $\begin{array}{c}1.0700 \\
(1.3142)\end{array}$ & $\begin{array}{c}1.0704 \\
(1.2023)\end{array}$ \\
\hline & $\mathrm{d}-1$ & $\begin{array}{c}-6.1347 \\
(-1.5102)\end{array}$ & - & $\begin{array}{c}-5.7048 \\
(-2.0517)\end{array}$ & - \\
\hline & $c-1$ & $\begin{array}{c}-0.5154 \\
(-1.2105)\end{array}$ & $\begin{array}{c}-0.6331 \\
(-8.4719)\end{array}$ & - & - \\
\hline \multicolumn{6}{|c|}{ Mean Efficiencies by Cooperative } \\
\hline Firm & NOBS & & & & \\
\hline 1 & 2 & 0.7972 & 0.8115 & 0.7824 & 0.7694 \\
\hline 2 & 2 & 0.8336 & 0.8260 & 0.8398 & 0.8093 \\
\hline 3 & 2 & 0.8061 & 0.8225 & 0.7891 & 0.7839 \\
\hline 4 & 2 & 0.7971 & 0.8082 & 0.7923 & 0.7853 \\
\hline 5 & 2 & 0.7874 & 0.8031 & 0.7829 & 0.7810 \\
\hline 6 & 2 & 0.8926 & 0.8881 & 0.8925 & 0.8771 \\
\hline 7 & 2 & 0.8768 & 0.8813 & 0.8739 & 0.8705 \\
\hline 8 & 2 & 0.7469 & 0.7629 & 0.7442 & 0.7328 \\
\hline 9 & 2 & 0.8096 & 0.8106 & 0.7873 & 0.7520 \\
\hline 10 & 2 & 0.6837 & 0.6736 & 0.6804 & 0.6131 \\
\hline 11 & 2 & 0.5921 & 0.6174 & 0.5670 & 0.5432 \\
\hline 12 & 2 & 0.8388 & 0.8394 & 0.8111 & 0.7772 \\
\hline 13 & 2 & 0.8941 & 0.8954 & 0.8849 & 0.8761 \\
\hline
\end{tabular}


Table 3. continued

\begin{tabular}{|c|c|c|c|c|c|}
\hline \multicolumn{2}{|c|}{ Mean Efficiencies by Cooperative } & \multicolumn{4}{|c|}{ MLE Parameter Estimates } \\
\hline \multirow[b]{2}{*}{ Firm } & \multirow[b]{2}{*}{ NOBS } & \multicolumn{4}{|c|}{ Model } \\
\hline & & 1 & 2 & 3 & 4 \\
\hline 14 & 2 & 0.8053 & 0.8222 & 0.7690 & 0.7578 \\
\hline 15 & 2 & 0.7370 & 0.7250 & 0.7546 & 0.7033 \\
\hline 16 & 2 & 0.8049 & 0.8182 & 0.7994 & 0.7971 \\
\hline 17 & 2 & 0.8289 & 0.8287 & 0.8324 & 0.8115 \\
\hline 18 & 2 & 0.7786 & 0.7925 & 0.7690 & 0.7554 \\
\hline 19 & 2 & 0.8907 & 0.8159 & 0.8222 & 0.8191 \\
\hline 20 & 2 & 0.7393 & 0.7541 & 0.7365 & 0.7190 \\
\hline 21 & 2 & 0.8710 & 0.8577 & 0.8407 & 0.7770 \\
\hline 22 & 2 & 0.7443 & 0.7185 & 0.7593 & 0.6787 \\
\hline 23 & 2 & 0.7122 & 0.7219 & 0.7287 & 0.7111 \\
\hline 24 & 2 & 0.8503 & 0.8544 & 0.8492 & 0.8396 \\
\hline 25 & 2 & 0.7336 & 0.7566 & 0.7155 & 0.7134 \\
\hline 26 & 2 & 0.8782 & 0.8311 & 0.8832 & 0.7912 \\
\hline 27 & 2 & 0.8504 & 0.8567 & 0.8575 & 0.8563 \\
\hline 28 & 2 & 0.8534 & 0.8713 & 0.7891 & 0.7862 \\
\hline 29 & 2 & 0.7436 & 0.7688 & 0.7095 & 0.7025 \\
\hline 30 & 2 & 0.6572 & 0.6967 & 0.5904 & 0.5719 \\
\hline 31 & 2 & 0.8565 & 0.8301 & 0.8578 & 0.7966 \\
\hline 32 & 2 & 0.8356 & 0.8475 & 0.8147 & 0.8079 \\
\hline 33 & 2 & 0.7985 & 0.7690 & 0.8233 & 0.7666 \\
\hline 34 & 2 & 0.9286 & 0.9330 & 0.9080 & 0.9091 \\
\hline 35 & 2 & 0.9290 & 0.9261 & 0.9295 & 0.9276 \\
\hline 36 & 2 & 0.8071 & 0.8184 & 0.8117 & 0.8120 \\
\hline 37 & 2 & 0.8825 & 0.8891 & 0.8538 & 0.8455 \\
\hline 38 & 2 & 0.7539 & 0.7717 & 0.7292 & 0.7200 \\
\hline 39 & 2 & 0.8467 & 0.8566 & 0.8386 & 0.8399 \\
\hline 40 & 2 & 0.8467 & 0.8534 & 0.8531 & 0.8542 \\
\hline 41 & 2 & 0.7825 & 0.7892 & 0.7441 & 0.7074 \\
\hline 42 & 2 & 0.6584 & 0.6454 & 0.5786 & 0.4752 \\
\hline 43 & 2 & 0.8559 & 0.8229 & 0.8713 & 0.8112 \\
\hline 44 & 2 & 0.8426 & 0.8496 & 0.8460 & 0.8414 \\
\hline 45 & 2 & 0.9256 & 0.9260 & 0.9274 & 0.9278 \\
\hline 46 & 2 & 0.7928 & 0.8043 & 0.8023 & 0.8033 \\
\hline 47 & 2 & 0.7444 & 0.7556 & 0.7673 & 0.7625 \\
\hline 48 & 2 & 0.8367 & 0.8509 & 0.8118 & 0.8133 \\
\hline 49 & 2 & 0.8113 & 0.8248 & 0.8048 & 0.8027 \\
\hline 50 & 2 & 0.7278 & 0.6855 & 0.6937 & 0.5591 \\
\hline 51 & 2 & 0.7418 & 0.7638 & 0.6928 & 0.6776 \\
\hline 52 & 2 & 0.8895 & 0.8951 & 0.8731 & 0.8706 \\
\hline 53 & 2 & 0.8358 & 0.7778 & 0.7960 & 0.6113 \\
\hline 54 & 2 & 0.6595 & 0.6907 & 0.6251 & 0.6126 \\
\hline 55 & 2 & 0.7516 & 0.7110 & 0.7216 & 0.5923 \\
\hline \multicolumn{2}{|c|}{ Uverall Mean Score } & 0.8028 & 0.8059 & 0.7901 & 0.7632 \\
\hline
\end{tabular}


Table 4. Panel frontier results for furniture cooperatives. Dependent Variable: $\ln y_{\text {it }}$

\begin{tabular}{|c|c|c|c|c|c|}
\hline \multirow{3}{*}{$\begin{array}{c}\text { Independent } \\
\text { Variable }\end{array}$} & \multirow[b]{3}{*}{ Coefficient } & \multicolumn{4}{|c|}{ MLE Parameter Estimates } \\
\hline & & \multicolumn{4}{|c|}{ Model } \\
\hline & & 1 & 2 & 3 & 4 \\
\hline Constant & $a_{0}$ & $\begin{array}{c}3.7444 \\
(4.0135)\end{array}$ & $\begin{array}{c}4.1210 \\
(4.2149)\end{array}$ & $\begin{array}{c}3.5304 \\
(5.3755)\end{array}$ & $\begin{array}{c}3.9651 \\
(6.7151)\end{array}$ \\
\hline $\ln K_{i t}$ & $a_{1}$ & $\begin{array}{c}0.2759 \\
(1.2024)\end{array}$ & $\begin{array}{c}0.1726 \\
(0.4705)\end{array}$ & $\begin{array}{c}0.2795 \\
(2.1170)\end{array}$ & $\begin{array}{c}0.1411 \\
(1.2536)\end{array}$ \\
\hline $\ln L_{i t}$ & $a_{2}$ & $\begin{array}{c}0.8866 \\
(3.5658)\end{array}$ & $\begin{array}{c}0.9717 \\
(1.2200)\end{array}$ & $\begin{array}{c}0.8840 \\
(8.9588)\end{array}$ & $\begin{array}{c}1.0293 \\
(10.9101)\end{array}$ \\
\hline$\left(\mathrm{K}^{\mathrm{E}} / \mathrm{K}\right)_{\mathrm{it}}$ & $a_{3}$ & $\begin{array}{c}-0.8206 \\
(-0.8183)\end{array}$ & - & $\begin{array}{c}-0.9007 \\
(-1.5425)\end{array}$ & - \\
\hline \multirow[t]{9}{*}{$\left(\mathrm{L}^{\mathrm{N}} / \mathrm{L}\right)_{\text {it }}$} & $\mathbf{a}_{4}$ & $\begin{array}{c}-0.6856 \\
(-2.2005)\end{array}$ & $\begin{array}{c}-0.7385 \\
(-1.9891)\end{array}$ & - & - \\
\hline & $\tilde{\sigma}^{2}$ & $\begin{array}{c}0.1920 \\
(2.7934)\end{array}$ & $\begin{array}{c}0.2219 \\
(0.6404)\end{array}$ & $\begin{array}{c}0.1826 \\
(1.2874)\end{array}$ & $\begin{array}{c}0.2308 \\
(1.4005)\end{array}$ \\
\hline & $\gamma$ & $\begin{array}{c}0.8353 \\
(8.0606)\end{array}$ & $\begin{array}{c}0.8719 \\
(3.2549)\end{array}$ & $\begin{array}{c}0.7262 \\
(2.5192)\end{array}$ & $\begin{array}{c}0.7700 \\
(3.4276)\end{array}$ \\
\hline & $\mu$ & 0 & 0 & 0 & 0 \\
\hline & $\ln £$ & -3.7674 & -4.0023 & -7.4889 & -8.7876 \\
\hline & $\chi_{(1)}^{2}$ & 13.2057 & 16.6850 & 8.6422 & 9.3057 \\
\hline & RTS & $\begin{array}{c}1.1625 \\
(2.6144)\end{array}$ & $\begin{array}{c}1.1443 \\
(0.3041)\end{array}$ & $\begin{array}{c}1.1635 \\
(1.7275)\end{array}$ & $\begin{array}{c}1.1704 \\
(1.9329)\end{array}$ \\
\hline & $d-1$ & $\begin{array}{c}-2.9743 \\
(-0.9180)\end{array}$ & - & $\begin{array}{c}-3.2225 \\
(-1.7608)\end{array}$ & - \\
\hline & $c-1$ & $\begin{array}{c}-0.7733 \\
(-0.6660)\end{array}$ & $\begin{array}{c}-0.7600 \\
(-1.8176)\end{array}$ & - & - \\
\hline \multicolumn{6}{|c|}{ Mean Efficiencies by Cooperative } \\
\hline Firm & NOBS & & & & \\
\hline 1 & 2 & 0.7713 & 0.6654 & 0.8498 & 0.7782 \\
\hline 2 & 2 & 0.8799 & 0.8910 & 0.7445 & 0.7193 \\
\hline 3 & 2 & 0.6407 & 0.5520 & 0.7674 & 0.6640 \\
\hline 4 & 2 & 0.7467 & 0.7359 & 0.8220 & 0.8077 \\
\hline 5 & 1 & 0.7638 & 0.7265 & 0.8151 & 0.7622 \\
\hline 6 & 2 & 0.9477 & 0.9294 & 0.9213 & 0.8837 \\
\hline 7 & 2 & 0.7522 & 0.6462 & 0.7935 & 0.6839 \\
\hline 8 & 2 & 0.9046 & 0.9099 & 0.9165 & 0.9139 \\
\hline 9 & 2 & 0.6628 & 0.7382 & 0.7289 & 0.7850 \\
\hline 10 & 2 & 0.6301 & 0.5965 & 0.6277 & 0.5792 \\
\hline 11 & 1 & 0.8902 & 0.8986 & 0.8989 & 0.8897 \\
\hline 12 & 2 & 0.8536 & 0.8973 & 0.8533 & 0.8725 \\
\hline 13 & 2 & 0.9025 & 0.8785 & 0.9034 & 0.8719 \\
\hline
\end{tabular}


Table 4. continued

\begin{tabular}{cccccc}
\hline \multirow{2}{*}{ Mean Efficiencies by Cooperative } & \multicolumn{4}{c}{ MLE Parameter Estimates } \\
\cline { 3 - 6 } & & \multicolumn{5}{c}{ Model } \\
\cline { 3 - 6 } Firm & NOBS & 1 & 2 & 3 & 4 \\
\hline 14 & 2 & 0.5893 & 0.6092 & 0.6803 & 0.7064 \\
15 & 2 & 0.8219 & 0.8440 & 0.8927 & 0.9056 \\
16 & 2 & 0.4884 & 0.4256 & 0.5799 & 0.4832 \\
17 & 2 & 0.8859 & 0.8861 & 0.7992 & 0.7664 \\
18 & 2 & 0.8473 & 0.8879 & 0.7846 & 0.8187 \\
19 & 2 & 0.6662 & 0.7279 & 0.6213 & 0.6595 \\
20 & 2 & 0.5275 & 0.4745 & 0.5131 & 0.4721 \\
21 & 1 & 0.4531 & 0.4089 & 0.5547 & 0.5117 \\
22 & 1 & 0.6477 & 0.6987 & 0.7083 & 0.7607 \\
Overall Meanyyyyy Score & & 0.7422 & 0.7271 & 0.7648 & 0.7359 \\
\hline
\end{tabular}

Overall impressions: Output variation across cooperative enterprises is significantly related to input variation across enterprises in all four sectors. But that is only part of the story. Output variation is also significantly and positively affected by increases in participation in one sector. Output variation is also significantly affected by variation in productive efficiency in all four sectors. The conclusion is that any model that attempts to explain productivity performance exclusively in terms of conventionally measured inputs is bound to generate misleading results concerning the absolute and relative importance of those inputs. It is sometimes necessary to examine the extent to which members of the cooperative finance or supply these inputs, and it is always necessary to examine the efficiency with which management coordinates the employment of these variables.

\section{Summary and suggestions}

In this article we have employed stochastic frontier panel data techniques to investigate the magnitude and distribution of productive efficiency in samples of producer cooperatives operating in four sectors of French industry. The economic finding of primary interest concerns the role of efficiency variation in explaining observed output variation. That role is statistically significant in all four sectors. In addition, the role of two popular indicators of worker participation is significantly positive in one sector. This suggests that conclusions about productivity variation, and policy recommendations emanating therefrom, based on econometric analysis with symmetric error structures and without participation variables, may be very mislcading.

It would be of interest to reanalyze the same data using nonparametric, nonstochastic techniques to compare the performance of the two approaches. The nonparametric construction and decomposition of the Malmquist index into productivity variation and efficiency variation recently developed by Färe et al. [1989] would provide an ideal counterpart to our stochastic parametric approach. 
Table 5. Panel frontier results for public works cooperatives. Dependent Variable: $\ln y_{\text {it }}$

\begin{tabular}{|c|c|c|c|c|c|}
\hline \multirow{3}{*}{$\begin{array}{c}\text { Independent } \\
\text { Variable }\end{array}$} & \multirow[b]{3}{*}{ Coefficient } & \multicolumn{4}{|c|}{ MLE Parameter Estimates } \\
\hline & & \multicolumn{4}{|c|}{ Model } \\
\hline & & 1 & 2 & 3 & 4 \\
\hline Constant & $\mathrm{d}_{0}$ & $\begin{array}{c}4.1330 \\
(4.8408)\end{array}$ & $\begin{array}{c}4.5860 \\
(4.7209)\end{array}$ & $\begin{array}{c}4.2925 \\
(22.3826)\end{array}$ & $\begin{array}{r}4.5013 \\
(26.1761)\end{array}$ \\
\hline $\ln \mathrm{K}_{\mathrm{it}}$ & $a_{1}$ & $\begin{array}{c}0.2009 \\
(1.8209)\end{array}$ & $\begin{array}{c}0.1634 \\
(1.3118)\end{array}$ & $\begin{array}{c}0.1665 \\
(5.1396)\end{array}$ & $\begin{array}{c}0.1435 \\
(4.4837)\end{array}$ \\
\hline $\ln \mathrm{L}_{\mathrm{it}}$ & $a_{2}$ & $\begin{array}{c}0.8595 \\
(11.5334)\end{array}$ & $\begin{array}{c}0.8689 \\
(15.0722)\end{array}$ & $\begin{array}{c}0.9514 \\
(12.2352)\end{array}$ & $\begin{array}{r}0.9636 \\
(24.0603)\end{array}$ \\
\hline$\left(\mathrm{K}^{\mathrm{E} / \mathrm{K}}\right)_{\mathrm{it}}$ & $a_{3}$ & $\begin{array}{c}0.3656 \\
(1.1580)\end{array}$ & - & $\begin{array}{c}0.2960 \\
(1.2083)\end{array}$ & - \\
\hline \multirow[t]{9}{*}{$\left(\mathrm{L}^{\mathrm{N}} / \mathrm{L}\right)_{\mathrm{it}}$} & $a_{4}$ & $\begin{array}{c}0.3683 \\
(0.8930)\end{array}$ & $\begin{array}{c}0.2730 \\
(1.0726)\end{array}$ & - & - \\
\hline & $\tilde{\sigma}^{2}$ & $\begin{array}{c}0.1475 \\
(7.2110)\end{array}$ & $\begin{array}{c}0.2247 \\
(4.6128)\end{array}$ & $\begin{array}{c}0.1781 \\
(2.6249)\end{array}$ & $\begin{array}{c}0.1917 \\
(2.7814)\end{array}$ \\
\hline & $\gamma$ & $\begin{array}{c}0.8262 \\
(13.9386)\end{array}$ & $\begin{array}{c}0.8886 \\
(20.3922)\end{array}$ & $\begin{array}{c}0.8100 \\
(8.3282)\end{array}$ & $\begin{array}{c}0.8300 \\
(9.4723)\end{array}$ \\
\hline & $\mu$ & 0 & 0 & 0 & 0 \\
\hline & $\ln £$ & -4.1414 & -5.7854 & -6.0338 & -8.2930 \\
\hline & $x_{(1)}^{2}$ & 16.4122 & 22.7723 & 16.9051 & 16.7397 \\
\hline & RTS & $\begin{array}{c}1.0604 \\
(1.0307)\end{array}$ & $\begin{array}{c}1.0323 \\
(0.2843)\end{array}$ & $\begin{array}{c}1.1179 \\
(1.9815)\end{array}$ & $\begin{array}{c}1.1071 \\
(3.5581)\end{array}$ \\
\hline & $d-1$ & $\begin{array}{c}1.8198 \\
(2.1567)\end{array}$ & - & $\begin{array}{c}1.7778 \\
(1.0974)\end{array}$ & - \\
\hline & $c-1$ & $\begin{array}{c}0.4285 \\
(0.8399)\end{array}$ & $\begin{array}{c}0.4058 \\
(1.3410)\end{array}$ & - & - \\
\hline \multicolumn{6}{|c|}{ Mean Efficiencies by Cooperative } \\
\hline Firm & NOBS & & & & \\
\hline 1 & 2 & 0.7481 & 0.7252 & 0.7416 & 0.7407 \\
\hline 2 & 2 & 0.6879 & 0.5891 & 0.7270 & 0.6745 \\
\hline 3 & 2 & 0.6448 & 0.6227 & 0.7046 & 0.6337 \\
\hline 4 & 2 & 0.7258 & 0.6664 & 0.6859 & 0.6740 \\
\hline 5 & 2 & 0.6488 & 0.6043 & 0.6437 & 0.6232 \\
\hline 6 & 2 & 0.6633 & 0.5881 & 0.6361 & 0.6555 \\
\hline 7 & 2 & 0.6966 & 0.6601 & 0.6473 & 0.6260 \\
\hline 8 & 2 & 0.6167 & 0.5479 & 0.6139 & 0.5743 \\
\hline 9 & 2 & 0.9102 & 0.8964 & 0.9171 & 0.9232 \\
\hline 10 & 2 & 0.7739 & 0.7162 & 0.7050 & 0.6810 \\
\hline 11 & 2 & 0.6608 & 0.5664 & 0.5917 & 0.5642 \\
\hline 12 & 2 & 0.7200 & 0.6300 & 0.6797 & 0.6551 \\
\hline 13 & 2 & 0.9299 & 0.3515 & 0.8765 & 0.9291 \\
\hline
\end{tabular}


Table 5. continued

\begin{tabular}{|c|c|c|c|c|c|}
\hline \multicolumn{2}{|c|}{ Mean Efficiencies by Cooperative } & \multicolumn{4}{|c|}{ MLE Parameter Estimates } \\
\hline \multirow[b]{2}{*}{ Firm } & \multirow[b]{2}{*}{ NOBS } & \multicolumn{4}{|c|}{ Model } \\
\hline & & 1 & 2 & 3 & 4 \\
\hline 14 & 2 & 0.7997 & 0.6726 & 0.7550 & 0.7092 \\
\hline 15 & 2 & 0.7666 & 0.7883 & 0.8245 & 0.8547 \\
\hline 16 & 2 & 0.9615 & 0.9532 & 0.9620 & 0.9602 \\
\hline 17 & 2 & 0.8797 & 0.9560 & 0.3672 & 0.8525 \\
\hline 18 & 2 & 0.8647 & 0.7737 & 0.8157 & 0.7864 \\
\hline 19 & 2 & 0.7921 & 0.6647 & 0.7450 & 0.6879 \\
\hline 20 & 2 & 0.8713 & 0.7365 & 0.7927 & 0.7446 \\
\hline 21 & 2 & 0.8543 & 0.9261 & 0.8262 & 0.9006 \\
\hline 22 & 2 & 0.7733 & 0.6746 & 0.7613 & 0.7210 \\
\hline 23 & 2 & 0.8974 & 0.9293 & 0.8921 & 0.9411 \\
\hline 24 & 2 & 0.6994 & 0.6271 & 0.6240 & 0.6126 \\
\hline 25 & 2 & 0.6925 & 0.5804 & 0.6719 & 0.6239 \\
\hline 26 & 2 & 0.9484 & 0.9092 & 0.8991 & 0.8758 \\
\hline 27 & 2 & 0.8680 & 0.7605 & 0.8020 & 0.7528 \\
\hline 28 & 2 & 0.7746 & 0.6493 & 0.7581 & 0.7051 \\
\hline 29 & 2 & 0.4529 & 0.3944 & 0.4856 & 0.4689 \\
\hline 30 & 2 & 0.9290 & 0.8730 & 0.8767 & 0.8510 \\
\hline 31 & 1 & 0.8830 & 0.8365 & 0.8794 & 0.8608 \\
\hline 32 & 2 & 0.5077 & 0.4479 & 0.4879 & 0.4777 \\
\hline 33 & 2 & 0.5691 & 0.5480 & 0.6036 & 0.6292 \\
\hline 34 & 2 & 0.8852 & 0.7765 & 0.8211 & 0.7724 \\
\hline 35 & 2 & 0.8984 & 0.8049 & 0.7920 & 0.7543 \\
\hline 36 & 2 & 0.6442 & 0.5377 & 0.6434 & 0.5861 \\
\hline 37 & 2 & 0.9271 & 0.7857 & 0.9095 & 0.8442 \\
\hline 38 & 2 & 0.8640 & 0.7504 & 0.7938 & 0.7507 \\
\hline 39 & 1 & 0.7011 & 0.5484 & 0.7089 & 0.6295 \\
\hline 40 & 2 & 0.5049 & 0.4844 & 0.5395 & 0.5592 \\
\hline 41 & 2 & 0.6545 & 0.5281 & 0.6810 & 0.6220 \\
\hline 42 & 1 & 0.4631 & 0.4126 & 0.5028 & 0.4972 \\
\hline \multicolumn{2}{|c|}{ Overall Mean Score } & 0.7727 & 0.7238 & 0.7567 & 0.7471 \\
\hline
\end{tabular}

\section{Notes}

1. Our model is parametric, and so the decomposition we obtain is conditional on both the functional form of the production function we estimate (Cobb-Douglas) and the functional form of the error component intended to capture productive inefficiency (half-normal).

2. However, by segmenting his sample into size classes, Defourny was able to test hypotheses concerning variation of technical efficiency over size classes.

3. One can also mention Côté [1989], who measured technical efficiency in private, public and cooperative U.S. electric utilities, but his sample included only consumer cooperatives, and he estimated only mean technical efficiencies.

4. The Cobb-Douglas functional form is used in this study because single equation translog rarely works, and did not work with these data. 
5. Since internal and external capital resources are used together to finance most types of asset purchases, it is impossible to know precisely what proportion of fixed assets is internally financed. We took the percentage of equity capital held by workers (as opposed to the percentage held by nonworkers) as an approximation to this proportion.

6. This approximation has been applied before in this literature, by Jones and Svejnar [1985] and Defourny [1987], but only for the labor input. The approximations are obtained by taking Taylor series expansions of the two nonlinear participation terms in equation (6) around the points $\mathrm{d}=1$ and $\mathrm{c}=1$ respectively, and truncating each expansion at the first-order term. Lovell, Sickles, and Warren [1988] have shown that if $c=d=1$ the linear approximations are exact, and equation (7) correctly shows that participation has no effect on productivity. However if $c \neq 1$ or $d \neq 1$, then although equation (7) correctly identifies the directions of the participation effects, it overstates their magnitudes, and the approximation errors increase in magnitude as $c$ or $d$ depart from unity. Of course it would be possible to embed the nonlinear model (6) directly into a stochastic frontier panel data framework and avoid the approximation error issue altogether. We have not done so. Consequently, we interpret our empirical findings as establishing upper bounds on the likely impacts of participation on productivity in these sectors.

7. Initially we tried a two-stage formulation. In the first stage, we estimated a stochastic Cobb-Douglas production frontier (2). In the second stage, we attempted to use the two participation variables to explain variation in measured efficiency by performing regressions of the general form

$$
\hat{\mathrm{u}}_{\mathrm{i}}=\mathbf{f}\left(\mathrm{E}\left(\mathrm{K}_{\mathrm{it}}^{\mathrm{E}} / \mathrm{K}_{\mathrm{it}}\right), \mathrm{E}\left(\mathrm{L}_{\mathrm{it}}^{\mathrm{N}} / \mathrm{L}_{\mathrm{it}}\right)\right)
$$

where the expectation is taken over time. When we found no significant correlation between $\hat{u}_{i}$ and the means of the two participation indicators, we turned to the single stage formulation (8). In this formulation participation influences productivity not by influencing efficiency, but by altering production possibilities.

8. We use a computer program written by Coelli [1989].

9. $(d-1)=a_{3} / a_{1}=f\left(a_{1}, a_{3}\right)$ and $(c-1)=a_{4} / a_{2}=g\left(a_{2}, a_{4}\right)$. The functions $f$ and $g$ are nonlinear, and so we use linear approximations to obtain estimated standard errors of the estimated values of $d$ and $c$. If we have $\hat{b}=h(\hat{a})$, where $\hat{a}$ is a vector and $\vec{b}$ is a scalar and if $\nabla h$ is the gradient vector and $\Sigma$ is the variancecovariance matrix, then by approximation we have

$$
h(\hat{a})-h(a) \approx[\nabla h(a)]^{T}(\hat{a}-a),
$$

and the variance of $\hat{b}$ is given by

$$
\operatorname{var}(\hat{b})=[\nabla h(a)]^{\mathrm{T}} \Sigma[V \nabla h(a)] .
$$

See also N'Gbo [1991].

\section{References}

Aigner, D. C.A.K. Lovell, and P. Schmidt. (1977). "Formulation and Estimation of Stochastic frontier Production Function models." Journal of Econometrics 6(1), pp. 21-37.

Buttese, G.E. and T.J. Coelli (1988). "Prediction of Firm-Level Technical Efficiencies with a Generalized Frontier Production Function and Panel Data." Journal of Econometrics 38, pp. 387-99.

Battese, G.E., T.J. Coelli, and T.C. Colby (1989). "Estimation of Frontier Production Functions and the Efficiencies of Indian Farms Using Data from ICR ISAT's Village Level Studies." Joumal of Quantitative Economics 5 (2), pp. $327-48$.

Battese, G.E. and G.S. Corra (1977). "Estimation of a Production Frontier Model: With Application to the Pastoral Zone of Eastern Australia." Australian Journal of Agricultural Economics 21, pp. 169-79.

Brown, C. and J. Medoff (1978). "Trade Unions in the Productive Process." Joumal of Political Economy 86 (3) pp. 355-78.

Coelli, T.J. (1989). "Estimation of Frontier Production Functions: A Guide to the Computer Program 'Frontier'." Working Paper No. 34, Department of Econometrics, University of New England, Armidale, NSW, Australia. 
Confédération Générale des SCOP (1989). Bilans et Comptes de Résultat 1987 et 1988 . Fichiers de la Centrale des Bilans, Paris.

Côté, D. (1989). "Firm Efficiency and Ownership Structure: The Case of U.S. Electric Utilities Using Panel Data." Annals of Public and Cooperative Economics 60 (4), pp. 431-50.

Defourny, J. (1987). "La Performance économique comparée des coopératives de travailleurs: La cas des SCOP francaises." Thèse de doctorat, Unversité de Liège, Faculté de Droit, d'Economie et de Sciences Sociales.

Defourny, J. (1988). "Comparative Measures of Technical Efficiency for 500 French Workers' Cooperatives." Working Paper 88/07, CIRIEC, The University of Liege, Liege, Belgium. Forthcoming in D.C. Jones, and J. Svejnar (eds.), Advances in the Economic Analysis of Participatory Labor-Managed Firms, Volume 4. Greenwich, CT: JAI Press.

Defourny, J., S. Estrin, and D.C. Jones (1987. "The Effects of Workers' Participation on Enterprise Performance: Empirical Evidence from French Cooperatives." International Joumal of Industrial Organization 3, pp. 197-217.

Estrin, S., D.C. Jones, and J. Svejnar (1987). "The Productivity of Worker Participation: Producer Cooperatives in Western Economies." Journal of Comparative Economics 11 (1), pp. 40-61.

Färe, R., S. Grosskopf, B. Lindgren, and P. Roos (1989). "Productivity Developments in Swedish Hospitals: A Malmquist Output Index Approach." Paper presented at a Conference on New Uses of DEA in Management, IC ${ }^{2}$ Institute, The University of Texas, Austin, TX, September 27-29.

Jondrow, J., C.A.K. Lovell, I. Materov, and P. Schmidt (1982). "On the Estimation of Technical Inefficiency in the Stochastic Frontier Production Model." Journal of Econometrics 19 (2/3), pp. 233-38.

Jones, D.C. and J. Svejnar (1985). "Participation, Profit-Sharing, Worker Ownership and Efficiency in Italian Producer Cooperatives." Economica 52 (208), pp. 449-65.

Lovell, C.A.K., R. Sickles, and R. Warren (1988). "The Effect of Unionization on Labor Productivity: Some Additional Evidence." Journal of Labor Research 9 (1), pp. 55-63.

Meeusen, W. and J. van den Broeck (1977). "Efficiency Estimation from Cobb-Douglas Production Functions with Composed Error." International Economic Review 18, pp. 435-44.

N'Gbo, A.G.M. (1991). "Elasticité-prix de la demand de cacao et test d'exogeneité." Economie Appliquée 44 (1), pp. 123-40.

Sterner, T. (1990). "Ownership, Technology and Efficiency: An Empirical Study of Cooperatives, Multinationals and Domestic Enterprises in the Mexican Cement Industry." Journal of Comparative Economics 14 (2), pp. 286-300. 